\title{
Age-Dependent and Cell Class-Specific Modulation of Retinal Ganglion Cell Bursting Activity by GABA
}

\author{
Ken F. Fischer, ${ }^{1}$ Peter D. Lukasiewicz, ${ }^{1,2}$ and Rachel O. L. Wong ${ }^{1}$ \\ ${ }^{1}$ Department of Anatomy and Neurobiology and 2Department of Ophthalmology, Washington University School of \\ Medicine, St. Louis, Missouri 63110
}

\begin{abstract}
Competition for postsynaptic targets during development is thought to be driven by differences in temporal patterns of neuronal activity. In the ferret visual system, retinal ganglion cells that are responsive either to the onset (On) or to the offset (Off) of light exhibit similar patterns of spontaneous bursting activity early in development but later develop different bursting rhythms during the period when their axonal arbors segregate to occupy spatially distinct regions in the dorsal lateral geniculate nucleus. Here, we demonstrate that GABAergic transmission plays an important, although not exclusive, role in regulating the bursting patterns of morphologically identified On and Off ganglion cells. During the first and second postnatal weeks, blocking $\mathrm{GABA}_{\mathrm{A}}$ receptors leads to a decrease in the bursting activity of all ganglion cells, suggesting that GABA potentiates activity at the early ages. Subsequently, during the period of
\end{abstract}

Connections in the immature nervous system are often imprecise but become refined into highly ordered networks by maturity (Constantine-Paton et al., 1990; Goodman and Shatz, 1993; Katz and Shatz, 1996; Nguyen and Lichtman, 1996). Neural activity not only underlies the fine-tuning of projections from large populations of cells, but it is also necessary for establishing the appropriate receptive field properties of individual neurons during development (Sernagor and Grzywacz, 1996; Weliky and Katz, 1997). It is thought that information essential for the developmental restructuring of connections is encoded by specific temporal patterns of activity and that activity alone is insufficient for this process (Hebb, 1949; Willshaw and von der Malsburg, 1976; Miller et al., 1989; Miller, 1996). This idea is supported by findings in the visual system, in which the formation of ocular dominance columns and the emergence of orientation tuning in the primary visual cortex are dependent on the temporal relationship in the activity patterns of retinal ganglion cells during development (Stryker and Strickland, 1984; Weliky and Katz, 1997).

Before vision, the immature retina produces a pattern of correlated spontaneous rhythmic bursting activity when the connectivity of the retina with the dorsal lateral geniculate nucleus

Received Nov. 20, 1997; revised Feb. 26, 1998; accepted March 2, 1998.

This work was supported by National Institutes of Health Grant EY10699 and an Esther A. and Joseph Klingenstein fellowship to R.O.L.W., by National Institutes of Health Grant EY08922 to P.D.L., and by National Institutes of Health Core Grant EY02687 and a Research to Prevent Blindness grant to the Department of Ophthalmology, Washington University. We thank Dennis Oakley for much valued technical support, Dr. M. Gordon for advice on the statistical analysis, and W. T. Wong, E. D. Miller, and K. Myhr for their helpful comments on this manuscript.

Correspondence should be addressed to Dr. Rachel Oi Lun Wong, Department of Anatomy and Neurobiology, Washington University School of Medicine, 660 South Euclid, St. Louis, MO 63110.

Copyright (C) 1998 Society for Neuroscience $\quad 0270-6474 / 98 / 183767-12 \$ 05.00 / 0$
On-Off segregation in the geniculate nucleus, GABA suppresses ganglion cell bursting activity. In particular, On ganglion cells show significantly higher bursting rates when GABAergic transmission is blocked, but the bursting rates of Off ganglion cells are not affected systematically. Thus, developmental differences in the bursting rates of On and Off ganglion cells emerge as GABA becomes inhibitory and as it consistently and more strongly inhibits On compared with Off ganglion cells. Because in many parts of the CNS GABAergic circuits appear early in development, our results also implicate a potentially important and possibly general role for local inhibitory interneurons in creating distinct temporal patterns of presynaptic activity that are specific to each developmental period.

Key words: correlated bursting activity; ferret retina; spontaneous activity; amacrine cells; retinal development; GABA
(dLGN) is being shaped (Meister et al., 1991; Wong et al., 1993; Feller et al., 1996; Mooney et al., 1996). Retinal ganglion cells that are responsive either to the onset (On) or to the offset (Off) of light show an age-related change in their spontaneous bursting patterns (Wong and Oakley, 1996). This change coincides with the period when their axonal terminals segregate to innervate different targets within the dLGN. The bursting patterns of On and Off ganglion cells are indistinguishable before On-Off segregation in the dLGN but become distinct as segregation occurs. The generation of different bursting rhythms in On and Off ganglion cells results in a pattern of retinal activity that contains the appropriate cues for driving the activity-dependent remodeling of their axonal projection patterns (Hahm et al., 1991; Miller, 1996; Wong and Oakley, 1996; Cramer and Sur, 1997).

How are different patterns of activity generated in the same population of neurons during development? Because amacrine interneurons are also active spontaneously (Wong et al., 1995; Feller et al., 1996), we investigated whether GABAergic amacrine cells that are present by birth (Karne et al., 1997) play a role in regulating the temporal characteristics of the activity patterns of the ganglion cells. Using combined optical recording and intracellular dye-filling methods, we found that the effects of GABA altered with age; GABAergic inhibition arose only at the time when On and Off ganglion cell axonal arbors are segregating in the dLGN. At this time, On compared with Off ganglion cells exhibited a marked increase in their bursting rates in the presence of $\mathrm{GABA}_{\mathrm{A}}$ receptor antagonists. Thus, an "imbalance" in the activity levels of On and Off ganglion cells during the period of On-Off segregation is created primarily by the emergence of GABAergic inhibition and by a greater inhibition of On compared with Off ganglion cells. 


\section{MATERIALS AND METHODS}

Timed pregnant ferrets were obtained from Marshall farms (North Rose, New York). Ferret kits aged between birth (P0) and postnatal day 25 (P25) were used for the imaging studies. The numbers of animals used were three for $\mathrm{P} 0-\mathrm{P} 3$, nine for P5-P11, eight for P14-P18, and eight for $\mathrm{P} 20-\mathrm{P} 24$. The eyes were enucleated after the animals were killed with sodium pentobarbital ( $>150 \mathrm{mg} / \mathrm{ml}$; Nembutal) or after anesthesia with 4\% halothane (Halocarbon Laboratories, River Edge, NJ), followed immediately by decapitation. Retinae were removed from neonates in cold, oxygenated Ames medium (Sigma, St. Louis, MO), buffered to $\mathrm{pH}$ 7.4 by sodium HEPES (20 mM; Sigma). The retinae were floated onto a clean glass slide and mounted scleral side up on a piece of black Millipore filter paper (HABP; Millipore, Bedford, MA). For whole-cell recordings, pieces of retinae, $\sim 3 \times 3 \mathrm{~mm}$, were sectioned into $150-\mu \mathrm{m}$-thick slices using a fine razor blade mounted on a chopper with a micrometer-driven stage. For optical recordings, each retina was halved and mounted on filter paper.

Whole-cell recording. Details of the experimental setup for whole-cell recording are provided by Lukasiewicz and Roeder (1995). Whole-cell recordings were performed on ferret slices from ages P10 to P36 (25 cells). Current responses were evoked by puffing GABA focally in the inner plexiform layer (IPL) using a patch pipette containing $1 \mathrm{~mm}$ GABA (in Ames medium) and a Picospritzer (General Valve, Fairfield, $\mathrm{NJ}$ ). The pressure was adjusted to give a half-maximal or smaller response to GABA. GABA receptor antagonists 2-(3-carboxypropyl)-3amino-6-(4-methoxyphenyl)pyridazinium bromide or gabazine (SR95531; Research Biochemicals, Natick, MA), (-)-bicuculline methobromide, and picrotoxin (Sigma) were applied by locally superfusing the slice, under computer control. The control bath was Ames medium. The patch electrode solution consisted of (in $\mathrm{mM}$ ): cesium gluconate 106, CsCl 5.8, $\mathrm{NaCl} 3.4, \mathrm{MgCl}_{2}$ 0.4, EGTA 0.20, and sodium HEPES 10 (all from Sigma). In some recordings, the patch pipette was filled with an intracellular solution containing $0.03 \%$ Lucifer yellow $\mathrm{CH}$ (Sigma). The cells were voltage-clamped to $0 \mathrm{mV}$ where GABA responses were outward and easily detected $\left(E_{\mathrm{Cl}}\right.$ near $\left.-60 \mathrm{mV}\right)$.

Calcium imaging. The retinae were incubated in an oxygenated solution containing $10 \mu \mathrm{M}$ fura-2 AM in $0.001 \%$ pluronic acid (Molecular Probes, Eugene, OR) in Ames medium, $\mathrm{pH}$ 7.4. After incubation for one-half hour at room temperature, the incubation temperature was raised to $30^{\circ} \mathrm{C}$ for another one-half hour. The retinae were then washed in Ames medium and transferred to a temperature-controlled recording chamber, in which oxygenated Ames medium was superfused. For retinae older than P11, small slits were made on the retinal surface using a fine ophthalmic blade, and a concentrated solution of fura- $2 \mathrm{AM}[1 \mu \mathrm{g}$ of fura-2 AM in $1 \mu \mathrm{l}$ of DMSO (Sigma) and $5 \mu \mathrm{l}$ of $2.5 \%$ pluronic acid] was dropped over the slits (see Wong and Oakley, 1996). After 1-2 min, the retinae were incubated as described above.

The ganglion cell layer (GCL) was viewed using a low light level camera (SIT, Hamamatsu; Fryer Company, Huntley, IL), and images of the cells were acquired under computer control (Image 1-FL; Universal Imaging Corporation, West Chester, PA). Sequential excitation with 340 and $380 \mathrm{~nm}$ light was achieved using a shutter and a Lambda-10 filter wheel (Sutter Instruments, Novato, CA), and each pair of images was acquired and stored every 1 or $2 \mathrm{sec}$ on an optical disk (Panasonic TQ3038; Fryer Company). An estimate of intracellular calcium levels $\left(\left[\mathrm{Ca}^{2+}\right]_{\mathrm{i}}\right)$ was obtained from a calibration curve obtained before recording by plotting the ratio of fluorescence at 340 and $380 \mathrm{~nm}$ excitation in the presence of solutions of low and high calcium concentration (for details, see Wong and Oakley, 1996).

To assess the effects of the various antagonists, images were collected before and during superfusion of the solutions containing SR95531, bicuculline methobromide, picrotoxin, or strychnine (Sigma). A range of concentrations for each antagonist was applied (25-150 $\mu \mathrm{M}$ for $\mathrm{GABA}_{\mathrm{A}}$ receptor antagonists and $1-50 \mu \mathrm{M}$ for strychnine); the results presented here are those for which the concentrations of antagonist produced a consistent result at each age and across retinae. Recovery from the drug application was measured by collecting images after washout of the antagonists. All solutions were prepared on the day of recording. It was observed that the baseline value of $\left[\mathrm{Ca}^{2+}\right]_{i}$ decreased during the period when bicuculline was in the recording chamber, but no significant decrease occurred with SR95531 or picrotoxin. To examine whether the baseline drop in bicuculline was caused by a differential absorption of the excitation wavelengths, we added $100 \mu \mathrm{M}$ bicuculline to the calibration solutions (high and low calcium solutions) (see Wong and Oakley, 1996) and obtained the ratio of the images at 340 and $380 \mathrm{~nm}$ excitation. The ratio was noted to decrease with bicuculline; thus, the differential absorption of UV light by this agent contributes to the effect on the baseline.

Intracellular dye injections. The details of combining intracellular dye filling with calcium imaging are given in Wong and Oakley (1996). Briefly, after optical recording, an image of the field of view was printed on a thermal printer (Sony UP870MD; Fryer Company). With the guide of this image, an intracellular glass pipette filled with $1 \%$ Lucifer yellow $\mathrm{CH}$ (Sigma) and 4\% Neurobiotin (Vector Laboratories, Burlingame, CA) in Tris buffer, $\mathrm{pH} 8.2$, and back-filled with $0.1 \mathrm{M} \mathrm{LiCl}_{2}$ (Sigma), was guided into the somata of selected cells. The pipette tip and cells were viewed simultaneously under dim illumination using a Lucifer yellow filter set (Chroma Tech., Brattleboro, VT). After impalement of the cells, dye was injected using alternating positive and negative current, 1 $\mathrm{nA}$, at $50 \mathrm{~Hz}$ for a few seconds. An image of the dye-filled cell (the dendritic tree) was then acquired using the SIT camera and stored on optical disk. Because the dye-filled cells can be easily identified from the image of the fura-2-labeled somata, we can correlate the bursting patterns with the morphology of the injected cells.

The dendritic morphologies of the major classes of ganglion cell in the ferret retina are distinctive and can be recognized by P7 (Wingate et al., 1992; Wingate and Thompson, 1995). To identify a ganglion cell as an On- or Off-centered cell, the stratification level of the dendrites was recorded immediately after dye filling by focusing into the IPL (see Wong and Oakley, 1996). On-center ganglion cells stratify close to their somata (within three-fifths of the IPL thickness), whereas Off-center ganglion cells stratify closer to the inner nuclear layer (within the outer two-fifths of the IPL) (Nelson et al., 1978). The thickness of the IPL was determined as the difference between the depths of the GCL and the inner nuclear layer (INL) within each field of recording. The dendritic stratification levels were confirmed after fixation of the tissue with $4 \%$ paraformaldehyde in $0.1 \mathrm{M}$ phosphate buffer, $\mathrm{pH} 7.4$, and after immunoprocessing for Neurobiotin (see Wong and Oakley, 1996). Because it is not possible to determine physiologically the receptive field center sign in the ferret ganglion cells until after the photoreceptor circuits develop in the third postnatal week (Greiner and Weidman, 1981), the cells classified here according to their dendritic stratification levels are presumed to be On- or Off-centered cells.

Cross-correlation analysis. To obtain a quantitative comparison of the degree of correlated bursting activity between identified ganglion cells, we converted plots of $\left[\mathrm{Ca}^{2+}\right]_{i}$ with time to raster plots as described in Wong and Oakley (1996). Because the baseline constitutes a large number of minor fluctuations in $\left[\mathrm{Ca}^{2+}\right]_{i}$, cross-correlating the raw waveforms of $\left[\mathrm{Ca}^{2+}\right]_{i}$ with time leads to spurious correlations that often obscure the correlations of the peaks (bursts), which are represented by relatively fewer data points. Using Igor (Wavemetrics), we differentiated the $\left[\mathrm{Ca}^{2+}\right]_{\mathrm{i}}$ plots to obtain $\mathrm{d}\left[\mathrm{Ca}^{2+}\right]_{\mathrm{i}} / \mathrm{d} t$. By differentiating the raw calcium traces, the baseline fluctuates around 0.0 , and a threshold can be set to filter out the baseline noise. Each data point that exceeded the threshold was represented by a raster line. Thus, only $\left[\mathrm{Ca}^{2+}\right]_{\mathrm{i}}$ above the threshold was represented, and the number of raster lines representing each burst corresponded approximately to the duration (number of image frames) of the rise in intracellular calcium during the burst. Cross-correlation analysis (Spearman correlation matrices) was then performed on the raster plots using Systat 5.2 (SPSS, Chicago, IL). A correlation coefficient of 1.0 implies perfect correlation of the activity of the cell pair, a coefficient of 0.0 implies that the activity of two cells bear no strict temporal relationship, and a negative coefficient implies that the bursting of the two cells occur primarily at separate times. The accuracy in correlating the bursts of the cells depended primarily on an accurate conversion of the calcium "bursts" to raster plots. In some cases (although these represented $\sim 2-5 \%$ of all recorded bursts), when the changes in $\left[\mathrm{Ca}^{2+}\right]_{\mathrm{i}}$ are small, some calcium peaks are lost after setting the threshold. For each cell, the threshold is chosen as the minimal value for which the bursts observed in the raw data plot are as accurately represented by the raster plot as possible. This "error" is minimal in recordings in which the signal-to-noise is high, and thus the crosscorrelation analysis was performed only on recordings that met this criteria. See Figure $8 a$ for an example of this procedure.

\section{RESULTS}

\section{GABA-evoked responses in neonatal ganglion cells}

Every cell in the GCL of the neonatal ferret retina showed an increase in $\left[\mathrm{Ca}^{2+}\right]_{\mathrm{i}}$ in response to GABA $(50-200 \mu \mathrm{M})$ during the 
a
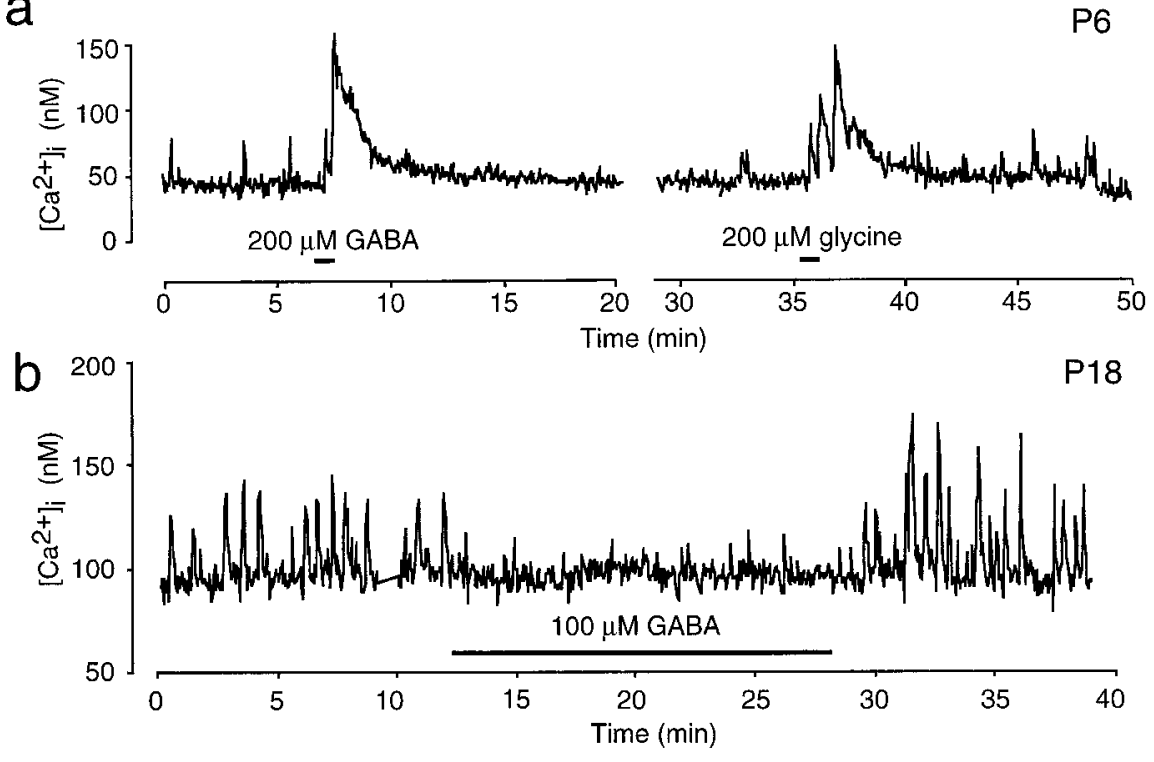

C
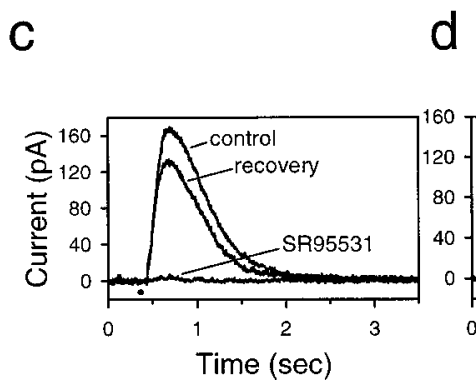

e
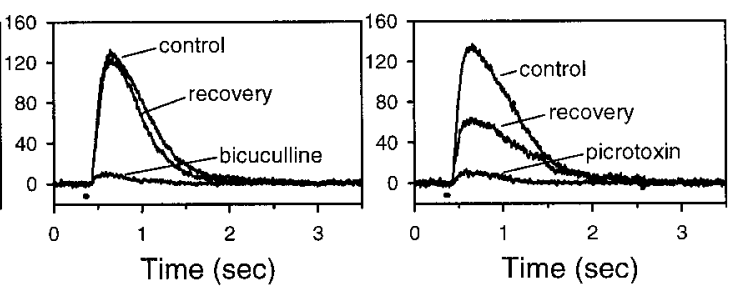

Figure 1. $a$, Response of a presumed ganglion cell at P6 to exogenous application of GABA and glycine. The horizontal bar denotes the duration of drug application. $b$, GABA suppression of the bursting activity of a P18 cell in the ganglion cell layer. The duration of GABA application is marked by the horizontal bar. $c-e$, Whole-cell recordings from a P10 ferret ganglion cell. SR95531 $(c ; 25 \mu \mathrm{M})$, bicuculline $(d ; 100 \mu \mathrm{M})$, and picrotoxin $(e ; 100 \mu \mathrm{M})$ reversibly blocked the ganglion cell current evoked by a puff of GABA $(1 \mathrm{~mm}$ in pipette; $5 \mathrm{psi} ; 50 \mathrm{msec}$ ) in the inner plexiform layer. Each current trace is an average of two to four responses. The short horizontal bar before the responses indicates the duration of the GABA puff. The cells were voltage-clamped at $0 \mathrm{mV}$. first $10 \mathrm{~d}$ after birth (three retinae; 180 cells analyzed). Figure $1 a$ demonstrates that cells that responded to GABA also responded to glycine. By contrast, after P15, bath application of GABA did not cause a rise in $\left[\mathrm{Ca}^{2+}\right]_{i}$ and instead suppressed spontaneous activity in every cell examined (two retinae; 40 cells analyzed). An example of this inhibitory effect of GABA on a P18 retina is shown in Figure $1 b$.

Previous experiments have suggested that the GABA-evoked response in mature ferret retinal ganglion cells is mediated primarily by $\mathrm{GABA}_{\mathrm{A}}$ receptors, in contrast to that in bipolar cells that is mediated by both $\mathrm{GABA}_{\mathrm{A}}$ and $\mathrm{GABA}_{\mathrm{C}}$ receptors (Lukasiewicz and Wong, 1997). To determine whether $\mathrm{GABA}_{\mathrm{A}}$ receptors are primarily responsible for GABA-evoked responses in ferret ganglion cells at all neonatal ages studied, we monitored responses of the ganglion cells (25 cells; P10-P36) to puffs of GABA using whole-cell recording techniques in the presence and absence of the $\mathrm{GABA}_{\mathrm{A}}$ receptor antagonists SR95531, bicuculline, and picrotoxin. Ganglion cells were identified as those cells in the ganglion cell layer that projected an axon in the nerve fiber layer, which was apparent after dye-filling with Lucifer yellow from the patch pipette. For every recorded cell and at every age studied, SR95531 completely abolished the ganglion cell response to puffs of GABA, and bicuculline and picrotoxin depressed the response by almost the same extent (Fig. $1 c-e$, e.g., P10 retina). These results indicate that $\mathrm{GABA}_{\mathrm{A}}$ receptors are present on neonatal ferret retinal ganglion cells and that these receptors are primarily responsible for GABA-evoked currents in these neurons.

\section{Age-related effects of $\mathrm{GABA}_{\mathrm{A}}$ receptor antagonists on ganglion cell bursting activity}

Having established that $\mathrm{GABA}_{\mathrm{A}}$ receptors are functional and that they mediate the responses of neonatal ganglion cells to GABA, we next examined whether endogenous GABA modulates the spontaneous bursting activity of these cells. We used calcium-imaging techniques to monitor the effects of SR95531, bicuculline, and picrotoxin on the burst frequency of cells in the ganglion cell layer at different postnatal ages. In these recordings, the bursting rhythms were plotted for cells with relatively large somata $(10-25 \mu \mathrm{m}$ in diameter), presumed to be ganglion cells, and for cells with smaller somata (4-9 $\mu \mathrm{m}$ in diameter), presumed to be displaced amacrine cells (see Henderson et al., 1988). Discussed below are recordings from presumed ganglion cells.

SR95531, bicuculline, and picrotoxin had distinct effects during three different periods of development. Between P0 and P10, either spontaneous bursting activity was abolished, or the burst frequencies were significantly reduced during application of 25-50 $\mu \mathrm{M}$ SR95531 (Fig. 2, P10). At P15, the effects of SR95531 were more diverse; some cells continued to burst without a noticeable change in burst frequency, whereas the bursting rates of other cells were reduced or abolished (Fig. 2, P15). In contrast, toward the end of the third postnatal week, SR95531 caused an increase in burst frequency in many cells, particularly those with relatively low bursting rates in the control (Ames) solution (Fig. 2, P21). At every age studied, the effects of bicuculline, picrotoxin, and SR95531 were similar (compare Figs. 2 and 3). The effects of 


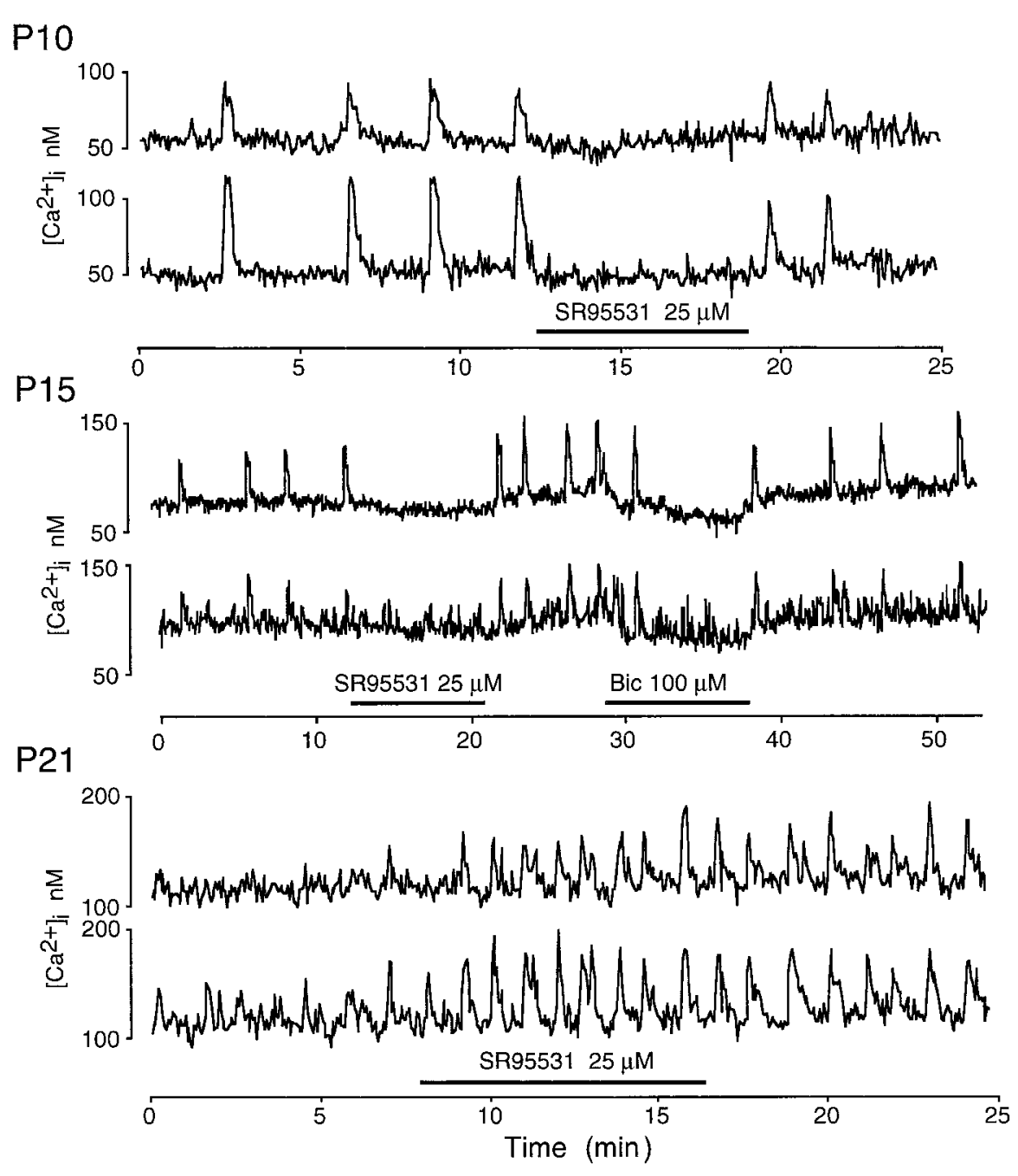

Figure 2. Effects of SR95531, a GABA A $_{\mathrm{A}}$ receptor antagonist, on the bursting activity of cells in the neonatal ferret ganglion cell layer. The effects of SR95531 were age-dependent. The horizontal bars indicate the duration of drug application. For the P21 recording, recovery from application of SR95531 was not observed during the short period after drug washout. Bic, Bicuculline.

these antagonists on burst frequency at the three developmental periods are summarized quantitatively in Figure 4. To determine the significance of the effects of each antagonist at each age group, Wilcoxon matched pairs signed rank tests were performed (Systat 5.2). For P1-P10, SR95531 (25 $\mu \mathrm{M})$, bicuculline (100 $\mu \mathrm{M})$, and picrotoxin $(100 \mu \mathrm{M})$ suppressed the bursting activity of every cell; this effect was highly significant for all three antagonists $(p<$ $0.0001)$. These antagonists caused a decrease in bursting to a mean level of 3-6\% of the baseline bursting rate, although the extent of suppression varied from cell to cell, ranging from $0 \%$ (complete blockade of activity) to $60 \%$ of the baseline frequency. Between P14 and P16, only $66-86 \%$ of all cells analyzed were suppressed by $\mathrm{GABA}_{\mathrm{A}}$ receptor antagonists $(p<0.0001$ for all antagonists). These cells burst at $38-46 \%$ of their baseline frequency in the presence of SR95531, bicuculline, and picrotoxin; the effects were significant $(p<0.0001)$. Within the populations of cells the activity of which was not suppressed significantly by the antagonists, SR95531 had no significant effect on the mean bursting rates ( $p>0.1 ; 1$ of 10 cells showed an increase), whereas bicuculline $(p<0.001)$ and picrotoxin $(p<0.005)$ caused a significant increase in mean burst frequency. However, bicuculline did not evoke an increase in burst frequency in 4 of the 18 cells in this latter population, and the bursting rates in 11 of 24 cells were unaffected by picrotoxin. When the effects of SR95531 and bicuculline are assessed in the same cells, both antagonists evoked a similar response (see Fig. 2, P15), indicating that quantitative differences in the mean bursting rates of the "unsuppressed" population at P14-P16 may be because of sampling rather than because SR95531, bicuculline, and picrotoxin act differently and because the effects of these antagonists are highly varied at this intermediate stage of development. SR95531, bicuculline, and picrotoxin produced two distinct effects at P19-P24; the burst frequency of one population of cells did not change significantly $(p>0.025)$, whereas another population showed a highly significant increase in burst frequency $(p<0.001)$, with a mean increase of $175-225 \%$ of the baseline frequency.

The results summarized in Figure 4 thus indicate that endogenous GABA promotes bursting during the first and second postnatal weeks but progressively acts to suppress bursting activity with maturation. In addition, although GABA acts uniformly across cells in the ganglion cell layer in the first and second postnatal weeks, GABA exhibits diverse effects on the bursting rates of retinal cells after the second postnatal week.

\section{Effects of glycinergic transmission on bursting activity}

Figure $1 a$ demonstrates that neonatal ferret ganglion cells respond to glycine. To determine whether glycine, like GABA, plays a role in modulating the bursting activity of retinal neurons at the various ages, we examined the bursting activity in the presence of strychnine, a glycine receptor antagonist, and com- 

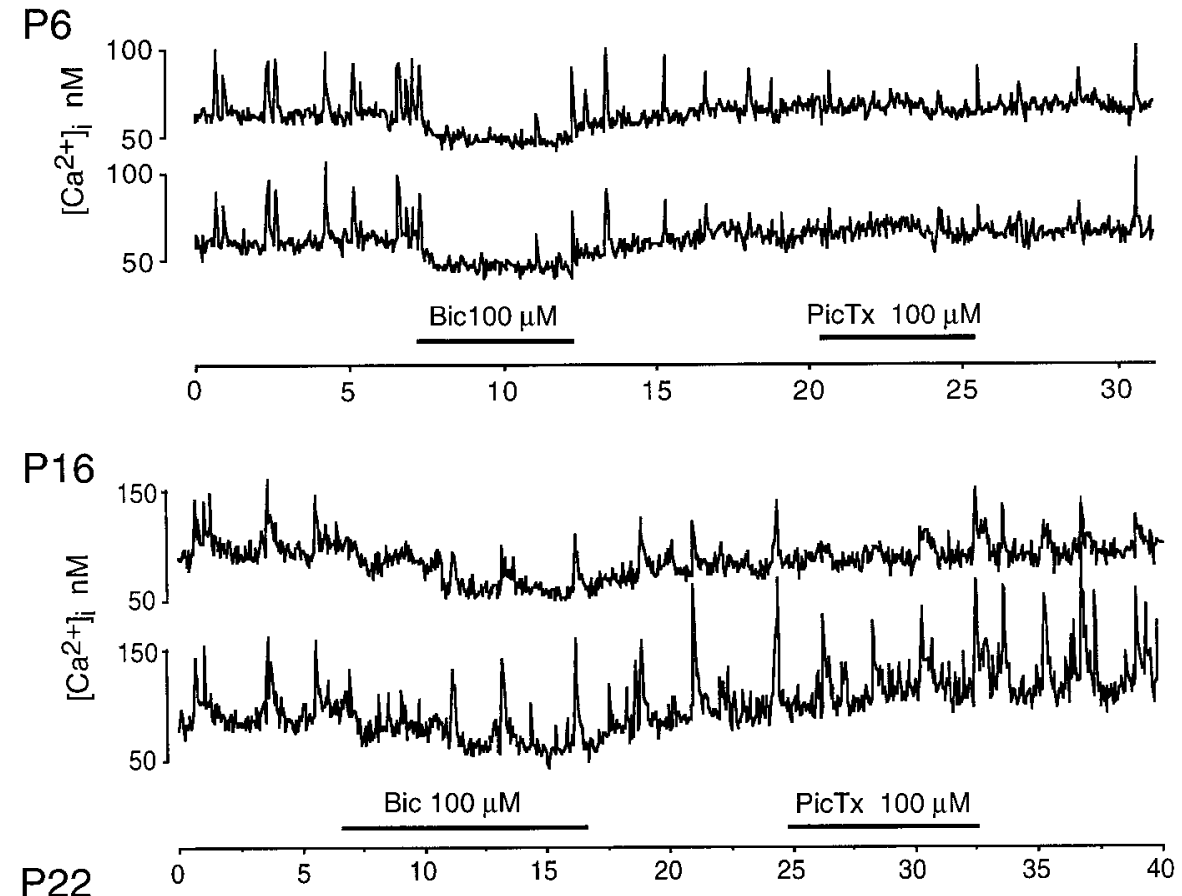

P22

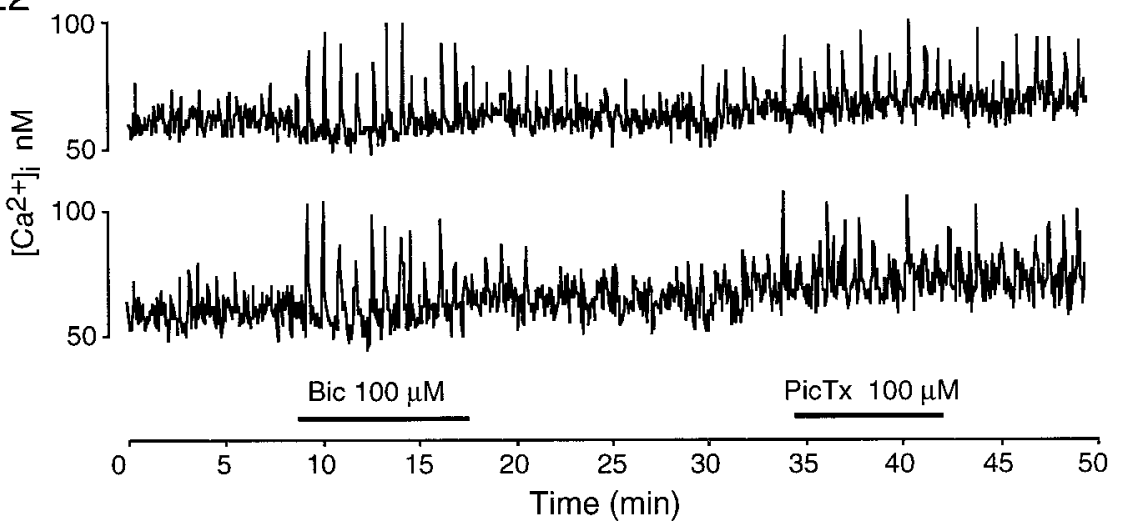

Figure 3. Effects of bicuculline (Bic) and picrotoxin $(P i c T x)$ on the bursting activity of cells in the neonatal ferret ganglion cell layer. Bicuculline and picrotoxin depressed bursting activity in cells in the P6 retina. By contrast, at P16, bicuculline and picrotoxin suppressed the activity of some, but not all, cells in the ganglion cell layer. At P22, bicuculline and picrotoxin caused an increase in bursting activity, seen here also as an increase in burst amplitude. pared this with the activity in the presence of bicuculline. Recordings were performed first in either antagonist (strychnine or bicuculline) and then in a medium containing both antagonists. Figure 5 demonstrates that at P8 and P18, strychnine ( $5 \mu \mathrm{M})$ alone did not alter the burst frequency of the cells in the GCL. Changes in bursting activity were detected only after superfusion with bicuculline. However, we noted that in the early neonates (before the third postnatal week), bursting activity was diminished or even abolished at higher concentrations of strychnine (10-50 $\mu \mathrm{M}$; $n=10$ retinae; $n=361$ cells; data not shown). Conversely, at these higher concentrations, strychnine caused an increase in the frequency of bursting by P21 (P21-P24: $n=5$ retinae; $n=149$ cells; data not shown). Because the effects of strychnine may not be specific at the high concentrations (Bähring et al., 1994), it is not possible without the availability of other glycine receptor antagonists to implicate conclusively the involvement of glycine in modulating the bursting activity. The conclusions that can be drawn from strychnine about glycinergic transmission are further complicated by the finding that glycine receptors in the retina may be differentially sensitive to this antagonist, although the concentrations of strychnine used in the current study are well above that necessary to reveal a component that is less sensitive to this antagonist (Han et al., 1997).

\section{GABAergic inhibition of putative On and Off ganglion cells}

Our current findings show that $\mathrm{GABA}_{\mathrm{A}}$ receptor antagonists caused a significant increase in the bursting activity of many, but not all, cells by P18. This differential effect of blocking $\mathrm{GABA}_{\mathrm{A}}$ receptors occurs during the period (between the third and fourth postnatal weeks) in which putative On- and Off-center ganglion cells develop different burst frequencies (Wong and Oakley, 1996). To examine whether the differential actions of GABA are cell class specific, we compared the activity patterns of morphologically identified ganglion cells in the presence and absence of bicuculline between the ages of P10 and P24. Putative On and Off ganglion cells were classified according to their dendritic stratification levels after intracellular dye-filling with Lucifer yellow (Wong and Oakley, 1996). $\beta$-Ganglion rather than $\alpha$-ganglion cells were selected for a quantitative assessment of the effects of $\mathrm{GABA}_{\mathrm{A}}$ receptor antagonists on On and Off cells, because $\beta$-cells are more prevalent in a single field of view (see Wong and Oakley, 1996).

In the older neonates, putative On and Off $\beta$-ganglion cells were observed to respond differently to bicuculline application. Figure 6 shows an example of a recording from a P20 retina. Two 


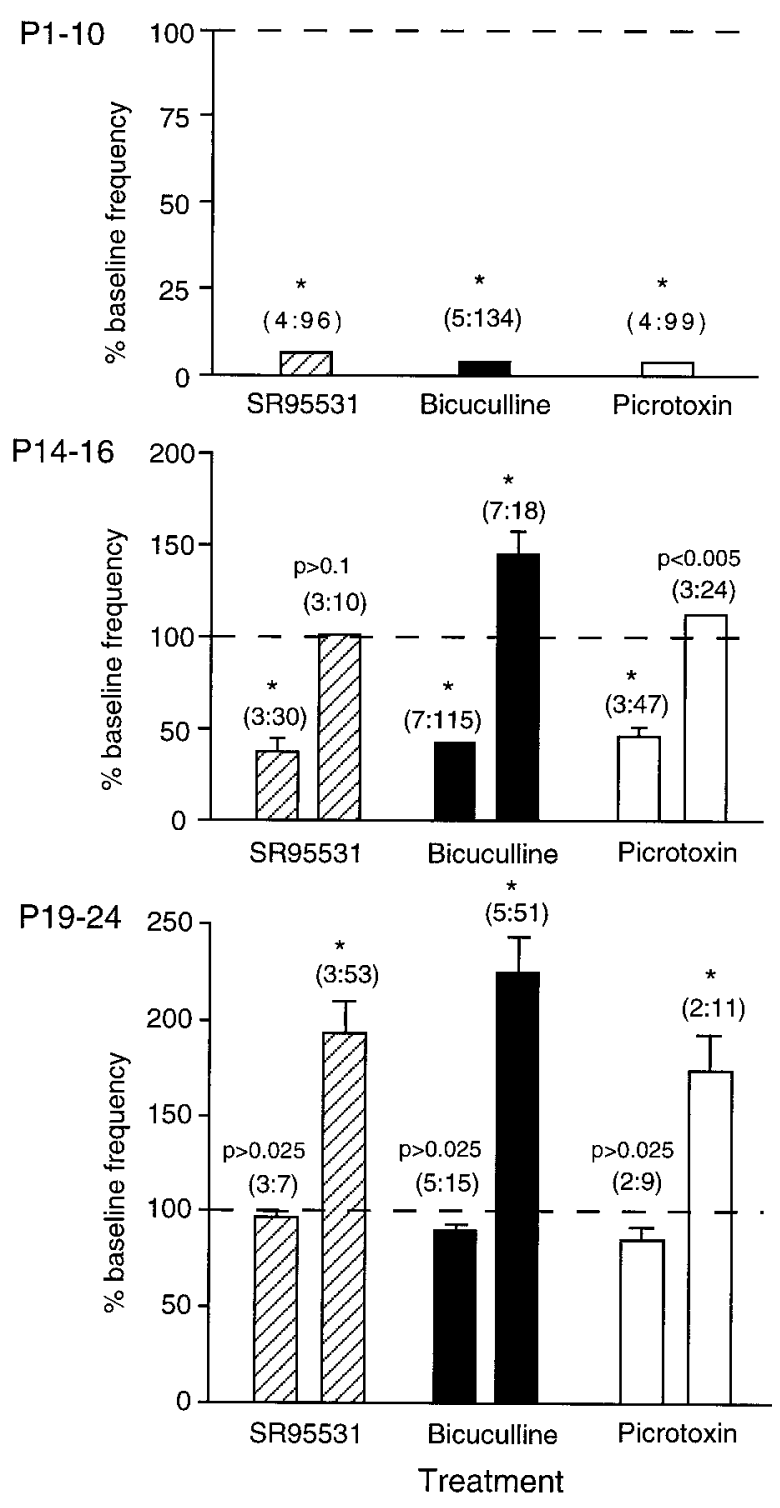

Figure 4. Quantitative summary of the effects of the $\mathrm{GABA}_{\mathrm{A}}$ receptor antagonists SR95531, bicuculline, and picrotoxin on the burst frequency of cells in the neonatal retinal ganglion cell layer at three different developmental periods. Burst frequencies during drug treatment are scored as a percentage of the baseline (predrug treatment, 100\%; dashed lines) burst frequency. The numbers above each histogram represent the numbers of retinae and cells (retinae: cells). For the age group P1-P10, every cell analyzed showed a decrease in bursting rate in SR95531, bicuculline, and picrotoxin. For the age groups P14-P16 and P19-P24, each antagonist elicited at least two different responses in the cells. For each antagonist, the number of cells that responded either with an increase, a decrease, or no change in bursting rates is given above each histogram. For example, for P14-P16, 30 of the 40 cells responded with a decrease in frequency in the presence of SR95531, whereas the 10 remaining cells showed no significant change in bursting rates. The significance of the effects is obtained after performing Wilcoxon matched pairs signed rank tests on the burst frequencies in the absence and presence of the antagonists. The asterisks represent a significance of $p<0.0001$; all other significance values are given above each histogram.

dye-filled $\beta$-ganglion cells are shown; cell 1 (Fig. $6 a$ ) is a presumed Off ganglion cell (dendritic stratification in the outer two-fifths of the IPL; see Materials and Methods), whereas cell 2 (Fig. $6 b$ ) is a presumed On ganglion cell (dendritic stratification in the inner three-fifths of the IPL). The bursting rhythms of these cells and four neighboring $\beta$-ganglion cells are shown in Figure $6 c$. In this recording, every On cell clearly showed an increase in bursting activity in the presence of bicuculline. In contrast, although the burst frequencies of two Off ganglion cells increased marginally, another Off cell (top trace) did not show an apparent increase in bursting rate in the presence of bicuculline. Addition of strychnine to the bicuculline-containing medium did not increase the bursting activity any further (Fig. $6 c$ ). Interestingly, even in the presence of bicuculline and strychnine, the bursts of On and Off cells consistently occurred in register.

A quantitative comparison of the burst frequency of On and Off $\beta$-cells at different ages in the absence and presence of bicuculline is presented in Figure 7. The burst frequencies of On and Off $\beta$-cells from each recorded region of a retina at the ages indicated are plotted for recordings in Ames medium (solid circles) or in bicuculline-containing Ames medium (open circles). As demonstrated previously (Wong and Oakley, 1996), On and Off $\beta$-ganglion cells have essentially the same burst frequency initially (see Fig. 7, P10 cells), but during the third postnatal week, Off $\beta$-ganglion cells develop a higher burst frequency compared with that of the On cells (Wong and Oakley, 1996) (see Fig. 7). The burst frequencies of On and Off cells diverge more markedly with age; Off cells adopt a burst frequency between 50 and 200 bursts/ $\mathrm{hr}$, whereas the burst frequency of On cells ranged between 10 and 50 bursts/hr (see Fig. 7; compare recordings of On and Off cells in Ames medium).

At P10 (Fig. 7), bicuculline reduced the burst frequency of every recorded On and Off $\beta$-cell, corroborating the results shown in Figure 4. At P16 and P17, this unidirectional effect is replaced by a more ambiguous one; no apparent systematic change in burst frequency can be detected for either On or Off cells. The effects were not related to cell class; of the $23 \beta$-cells in this age group, 17 cells showed a decrease in bursting, five cells showed an increase, and the activity of one cell was not altered (see also Fig. 4). However, between P18 and P24, the burst frequency of every recorded On $\beta$-cell was increased in the presence of bicuculline, with an average increase in frequency of 2.58- \pm 0.19 ( \pm SE)-fold. Wilcoxon matched pairs signed rank tests indicate that the significance of this increase for On cells is $p<0.0001$. In contrast, there was no systematic increase or decrease in the bursting rates of the population of Off $\beta$-cells for the same ages when bicuculline was applied (for the population of Off cells, the significance level of a change in burst frequency evoked by bicuculline was $p>$ 0.01). Of the Off cells that showed an increase in burst frequency, the mean increase in frequency was $1.27 \pm 0.06$ fold. Thus, overall, On compared with Off cells showed a consistent and greater increase in burst frequency in the absence of GABA inhibition. This implies that On cells are likely to participate in a larger fraction of bursts (waves) in the absence of GABAergic transmission. Between P20 and P24 (Fig. 7) in Ames medium (control), an On cell is active $30 \pm 0.06 \%$ of the time that an Off cell bursts ( $n=5$ retinae; $n=53$ cells). In the presence of bicuculline, this percentage increased to $65.6 \pm 0.12 \%$. Thus, bicuculline causes a significant increase in the participation of On cells in the bursting activity but does not equalize the bursting rates of On and Off cells.

The increase in bursting rates of On $\beta$-cells in the absence of GABAergic interactions suggests that the degree to which the activity of On and Off cells are correlated increases when GABAergic inhibition is removed. To examine this in greater detail, we first converted the raw measurements of $\left[\mathrm{Ca}^{2+}\right]_{i}$ to raster plots, which depict the distribution of bursts as vertical lines, 

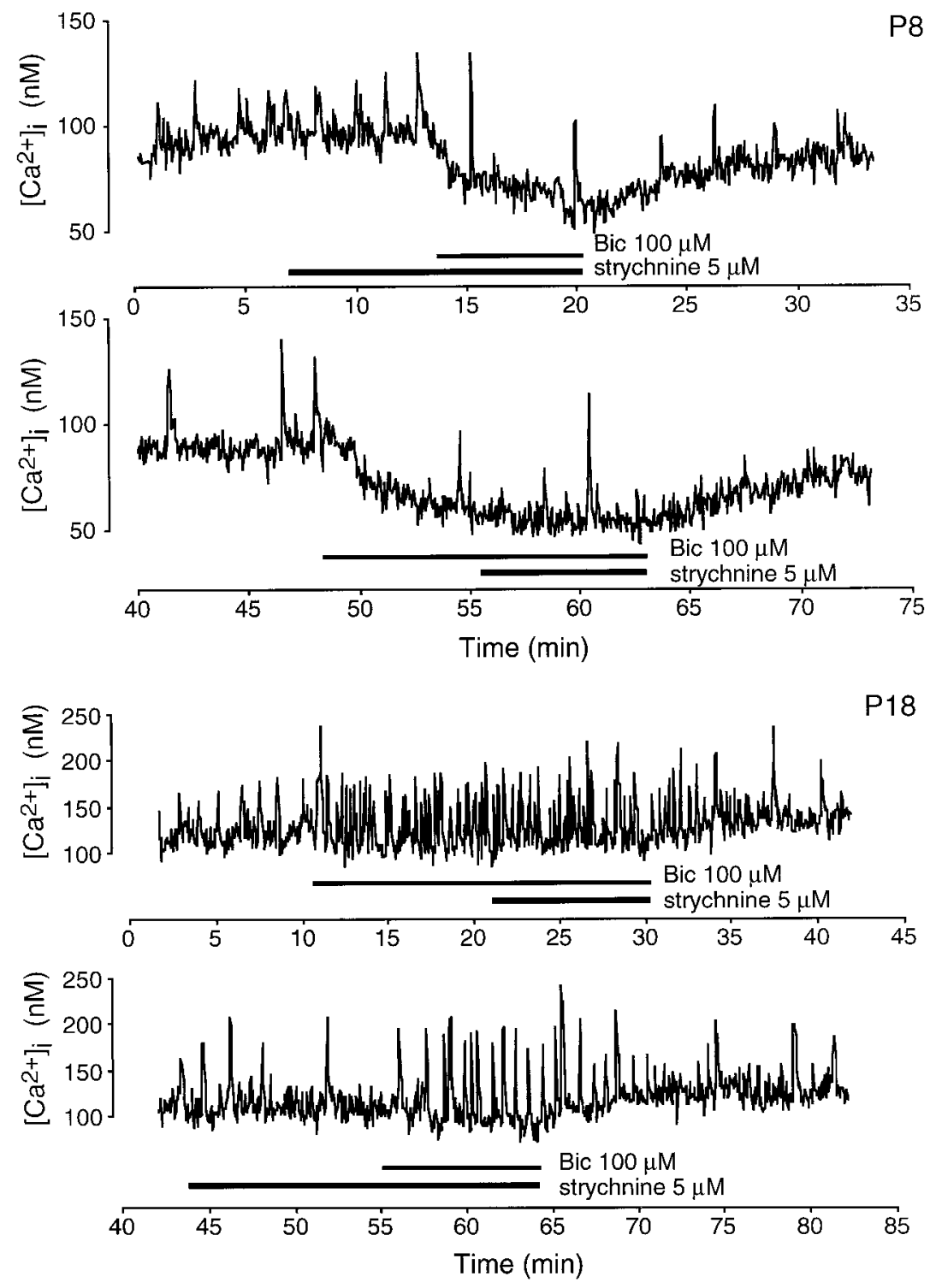

Figure 5. Strychnine is ineffective in changing the burst frequencies of the ganglion cells in $\mathrm{P} 8$ and $\mathrm{P} 18$ retinae. The burst frequencies of the cells only changed noticeably when bicuculline (Bic) was present. Horizontal bars indicate the duration in which each antagonist was present. and performed cross-correlation analyses on the rasters (Fig. 8a). The methods and motivation for generating these rasters are described in Wong and Oakley (1996) and in Materials and Methods.

Figure $8 b$ shows an example of raster plots for two On and two Off $\beta$-cells from a P20 retina in the presence and absence of bicuculline and strychnine. Figure $8 c$ shows the Spearman rank correlation coefficients (Systat 5.2) between the activity exhibited by pairs of cells from three retinae (P22-P24) in the presence and absence of bicuculline. A coefficient of 1.0 implies that the bursts of the two cells in a pair are perfectly correlated, whereas a coefficient of 0.0 indicates that the bursting patterns of the paired cells share no temporal relationship. The correlation coefficients for On-On pairs are not systematically affected by bicuculline (Wilcoxon matched pairs signed rank test; $p>0.1 ; n=16$ pairs). However, the coefficients for Off-Off pairs increased significantly in bicuculline ( $p<0.005 ; n=26$ pairs). Bicuculline also caused a highly significant increase in the correlation coefficients between On-Off pairs ( $p<0.001 ; n=52$ pairs), with every On-Off pair becoming more correlated in their activity in the absence of GABAergic transmission via $\mathrm{GABA}_{\mathrm{A}}$ receptors.

\section{DISCUSSION}

\section{Changing roles of GABA during development}

Our current results suggest that GABA modulates the frequency of bursting in neonatal ferret ganglion cells during the period when waves are present (P0-P25). GABAergic modulation of spontaneous bursting activity has also been detected in the developing turtle retina, in which bicuculline was found to suppress the bursting activity of ganglion cells (Sernagor and Grzywacz, 1994). In the neonatal ferret retina, the sign or direction of the modulatory effects of GABA is age-dependent. In the early neonate ( $\mathrm{P} 0-\mathrm{P} 11)$, spontaneous bursting activity of the ganglion cells is depressed when $\mathrm{GABA}_{\mathrm{A}}$ receptors are blocked, suggesting that GABA may be providing an excitatory drive on ganglion cells at these ages. In contrast, in older neonates (P18 onward), bursting activity is increased by $\mathrm{GABA}_{\mathrm{A}}$ receptor antagonists, implying an inhibitory role for GABA as the retina matures.

An early occurring "excitatory" effect of GABA on neonatal retinal ganglion cells has been reported previously in the rat (Bähring et al., 1994) and in other parts of the nervous system, such as the hippocampus (Ben-Ari et al., 1994; Leinekugel et al., 
a

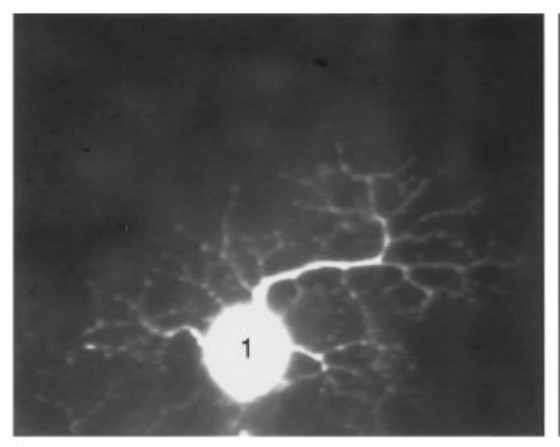

b

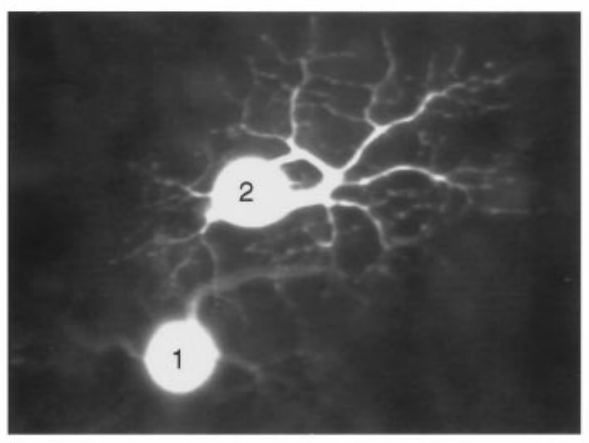

C

Figure 6. Dendritic morphology and bursting patterns of $\beta$-ganglion cells in a P20 ferret retina. $a, b$, A Lucifer yellow-filled $\beta$-cell (cell 1) with dendritic processes that stratified in the outer two-fifths (Off sublamina) of the IPL. $b$, A neighboring $\beta$-cell (cell 2) with dendrites stratifying in the inner three-fifths (On sublamina) of the IPL. $c$, Bursting patterns of cells 1 and 2 and four other neighboring $\beta$-cells in the absence and presence of bicuculline (Bic) and strychnine. Horizontal bars indicate duration of drug application.

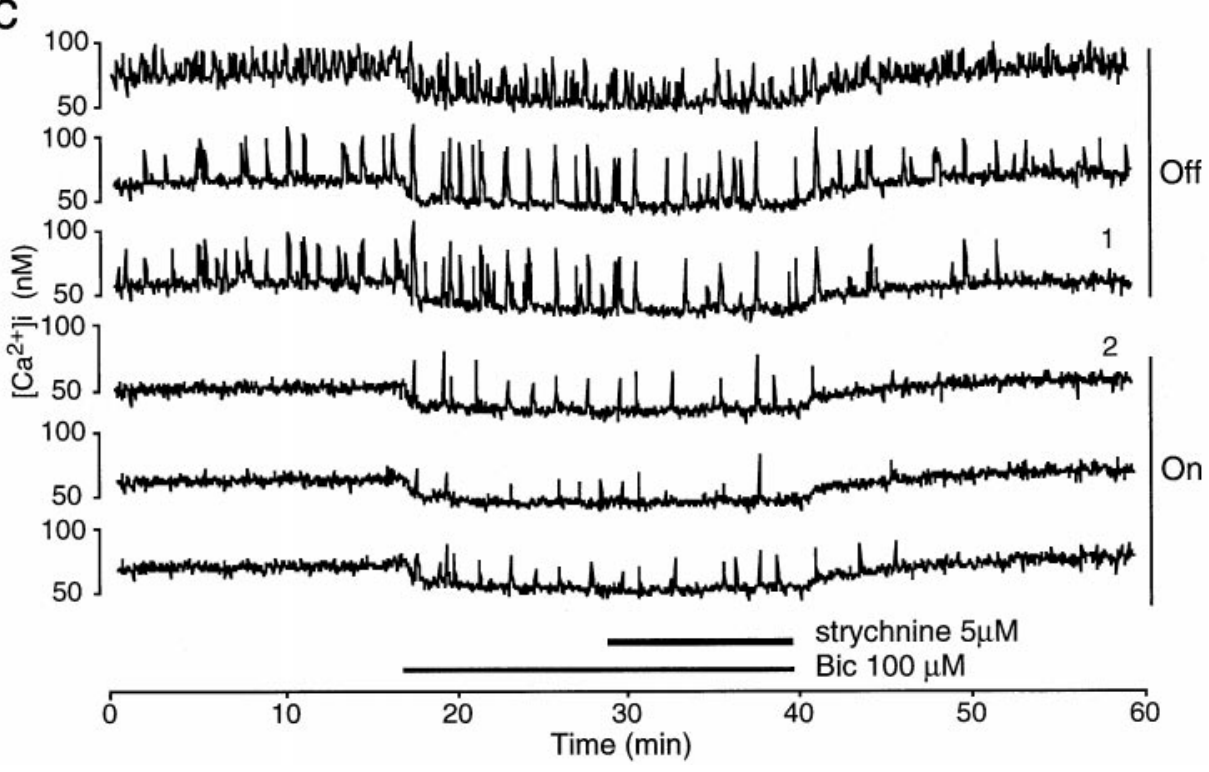

1997), hypothalamus (Chen et al., 1996), neocortex (Yuste and Katz, 1991), and spinal cord (Rohrbough and Spitzer, 1996). In all these systems, including the neonatal ferret retina, the excitatory effect of GABA is mediated by $\mathrm{GABA}_{\mathrm{A}}$ receptors. This early depolarizing response after activation of $\mathrm{GABA}_{\mathrm{A}}$ receptors has recently been shown to result from a high concentration of $\mathrm{Cl}^{-}$in the immature cell (Rohrbough and Spitzer, 1996). In RohonBeard spinal neurons of the Xenopus larvae, a high intracellular $\mathrm{Cl}^{-}$concentration is brought about by an inwardly directed $\mathrm{Cl}^{-}$ transport mechanism that sets the GABA reversal potential near $-30 \mathrm{mV}$ instead of $-60 \mathrm{mV}$. It is possible that similar transport mechanisms exist in early neonatal ferret ganglion cells, accounting for the early effects of $\mathrm{GABA}_{\mathrm{A}}$ receptor antagonists on the bursting activity. This transport mechanism may then be modified as ganglion cells mature, creating decreased intracellular $\mathrm{Cl}^{-}$ concentrations under which $\mathrm{GABA}_{\mathrm{A}}$ receptor antagonists cause an increase in bursting activity in the older neonates (P18-P25). Future experiments using perforated-patch recordings will test whether depolarizing or hyperpolarizing effects of GABA in the developing retina can be accounted for by developmental changes in this putative transport mechanism.

Our observation that $\mathrm{GABA}_{\mathrm{A}}$ receptor antagonists suppress the spontaneous activity of the early neonatal ganglion cells contrasts with those of Feller et al. (1996), who reported that SR95531 had no effects on the periodicity of the waves in the early postnatal period $(\mathrm{P} 0-\mathrm{P} 10)$. We believe that our current observa- tions support a role for GABA in modulating the bursting activity at the early ages (P0-P11). Because transmitter receptors in immature neurons may not be highly specific (Bähring et al., 1994), we used different pharmacological agents to block the GABA-evoked currents and elicited consistent changes in the bursting activity. Picrotoxin, which blocks $\mathrm{Cl}^{-}$conductance without binding to the GABA-binding sites, produced effects on the bursting activity similar to that observed using the competitive antagonists SR95531 and bicuculline. Our recordings monitor the responses of individual cells using calcium indicator dyes, in contrast to recordings of waves in low-power fields (Feller et al., 1996). But, over the entire field of view in our recordings, the antagonists affected the bursting activity of every cell in the early neonates similarly; thus differences in sampling are unlikely to resolve the difference in observations. Feller et al. (1996) also used whole-cell recordings to monitor the GABA-evoked component of the bursting activity; because the $\left[\mathrm{Cl}^{-}\right]_{\mathrm{i}}$ of the immature ganglion cells may normally be higher than that set by the pipette solution, excitatory, inward currents evoked by GABA would become outward in the whole-cell configuration.

What could be the functional role of a depolarizing influence of GABA in the early neonates? In the neonatal hippocampus, the depolarizing effect of GABA is found to reduce the $\mathrm{Mg}^{2+}$ block of NMDA receptors (Leinekugel et al., 1997). In the immature hippocampus, this synergistic excitatory effect of GABA and glutamate seems to play an important role in the 

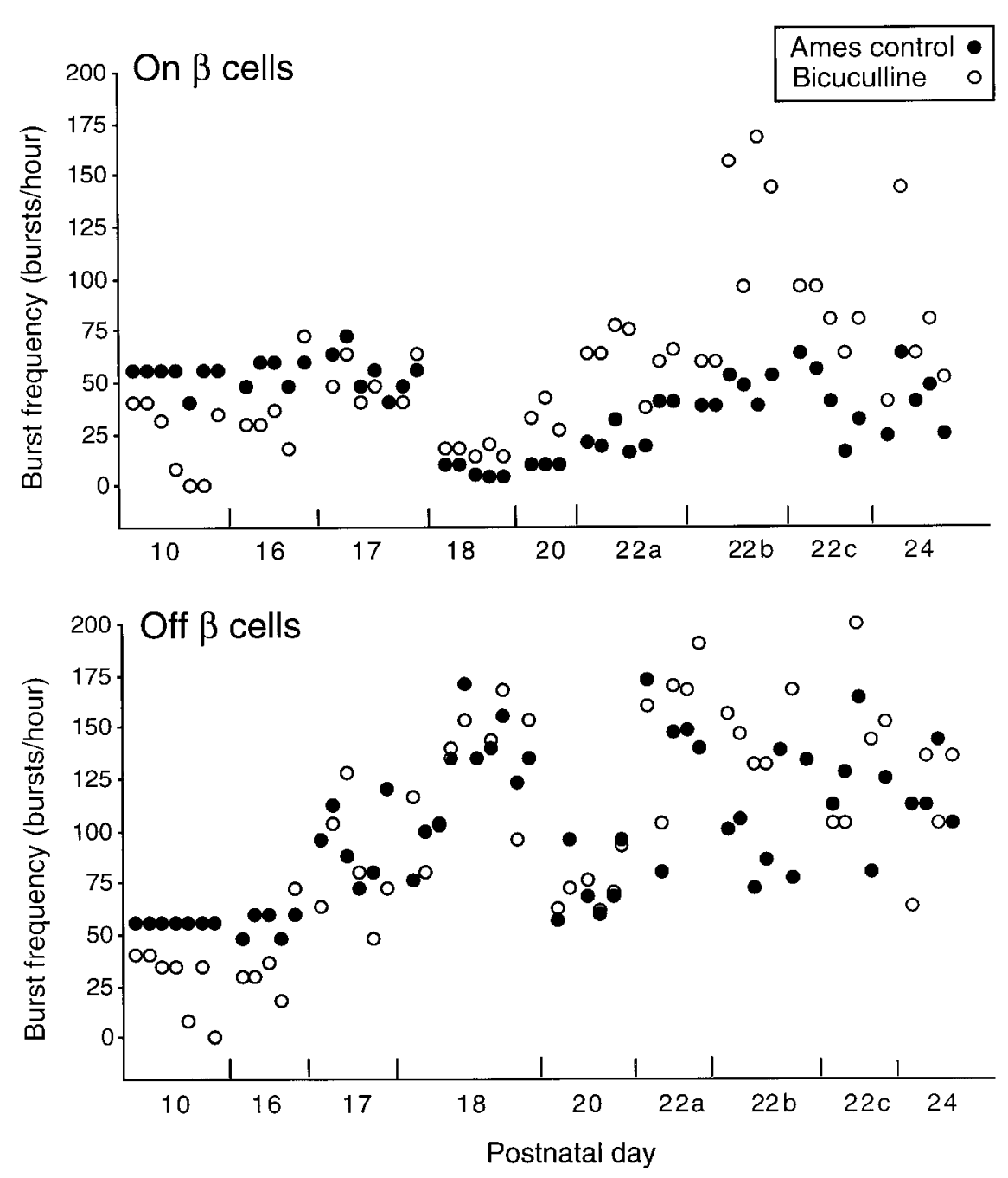

Figure 7. Burst frequencies of $\mathrm{On}$ and Off $\beta$-ganglion cells in Ames medium (control, solid circles) and in the presence of bicuculline (open circles) at various postnatal ages. For each recorded and dye-filled ganglion cell, the burst frequency during bicuculline application is plotted directly above or below the frequency observed in Ames medium. Putative On and Off cells in the same field of view in each retina are plotted within the boundary marked by the vertical ticks on the $x$ axis. generation and synchronization of periodically occurring giant depolarizing potentials, which are accompanied by increases in $\left[\mathrm{Ca}^{2+}\right]_{\mathrm{i}}$ (Leinekugel et al., 1996). In the early neonatal ferret retina, however, NMDA receptors do not seem to play a major role in the generation of the bursting activity (Wong et al., 1995). Nevertheless, by raising the general excitability of the cells, the release of GABA may ensure that neonatal ganglion cells are more susceptible to depolarization by another agonist, such as acetylcholine (Feller et al., 1996). Whether GABA is released tonically or only during a burst remains an issue to be resolved, although in our whole-cell recordings from the retina of older neonates (P21-25), bath application of bicuculline and picrotoxin was observed to cause a steady decrease in the baseline of the whole-cell current (14 of 18 recorded ganglion cells; data not shown), suggesting that GABA may be released tonically.

A point to be stressed here is that the effect of GABAergic transmission is modulatory; acetylcholine release causes spontaneous bursting in the ganglion cells (Feller et al., 1996), and GABA may act by setting the threshold above which bursting can occur. Furthermore, our results also demonstrate that GABAergic interactions do not influence the spread of activity between neighboring ganglion cells; even when the activity is reduced, the bursts of neighboring cells are still correlated temporally, and the activity is still likely to spread as a wave across the retina. As such, mechanisms other than GABAergic transmission must underlie the spatial spread of spontaneous bursting activity; these may include synaptic and nonsynaptic interactions between ganglion and amacrine cells. Several mechanisms, including the spread of extracellular potassium (Burgi and Grzywacz, 1994a,b), gapjunctional coupling (Penn et al., 1994), and synaptic interactions (Feller et al., 1996) have been proposed. The present data, however, do not distinguish between these possibilities.

Apart from the pronounced effects of $\mathrm{GABA}_{\mathrm{A}}$ receptor antagonists on burst frequencies, the antagonists also affect burst amplitude (the magnitude of the calcium peaks) of the cells. These amplitude changes may reflect corresponding changes in the spike rate within the burst. However, simultaneous electrical and optical recordings are necessary to confirm this relationship before the effects of burst amplitudes can be analyzed or interpreted.

\section{Age-related modulation of bursting rhythms of On and Off ganglion cells}

Our primary objective in the present study was to determine how On and Off ganglion cells develop different burst frequencies with age. Comparison of the bursting patterns of these cells suggests that GABAergic transmission contributes significantly to the observed differences in On and Off bursting rhythms. The consistent suppression of activity in On compared with Off cells may be achieved in several ways. First, it could be that there is a higher 
a
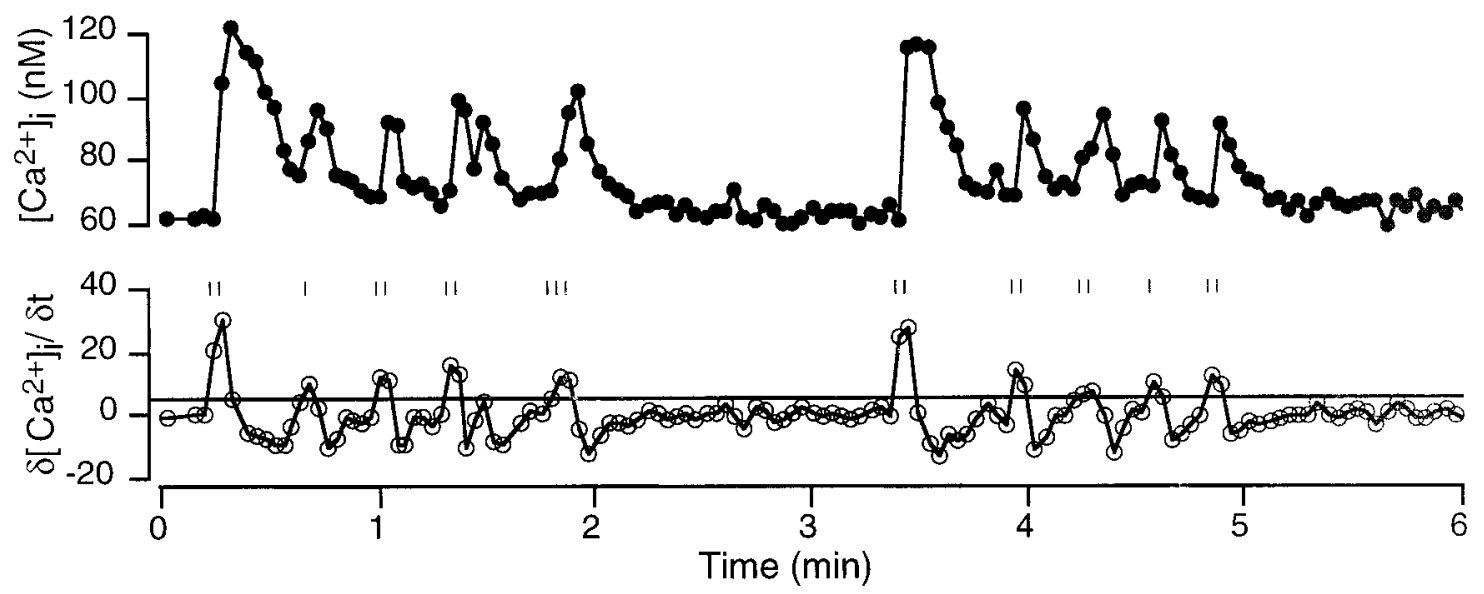

b

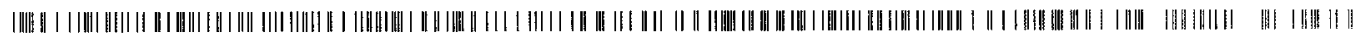

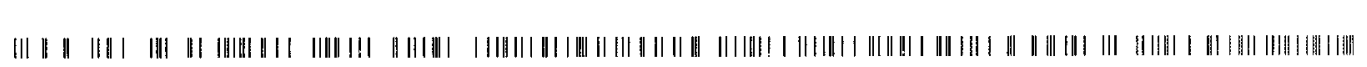
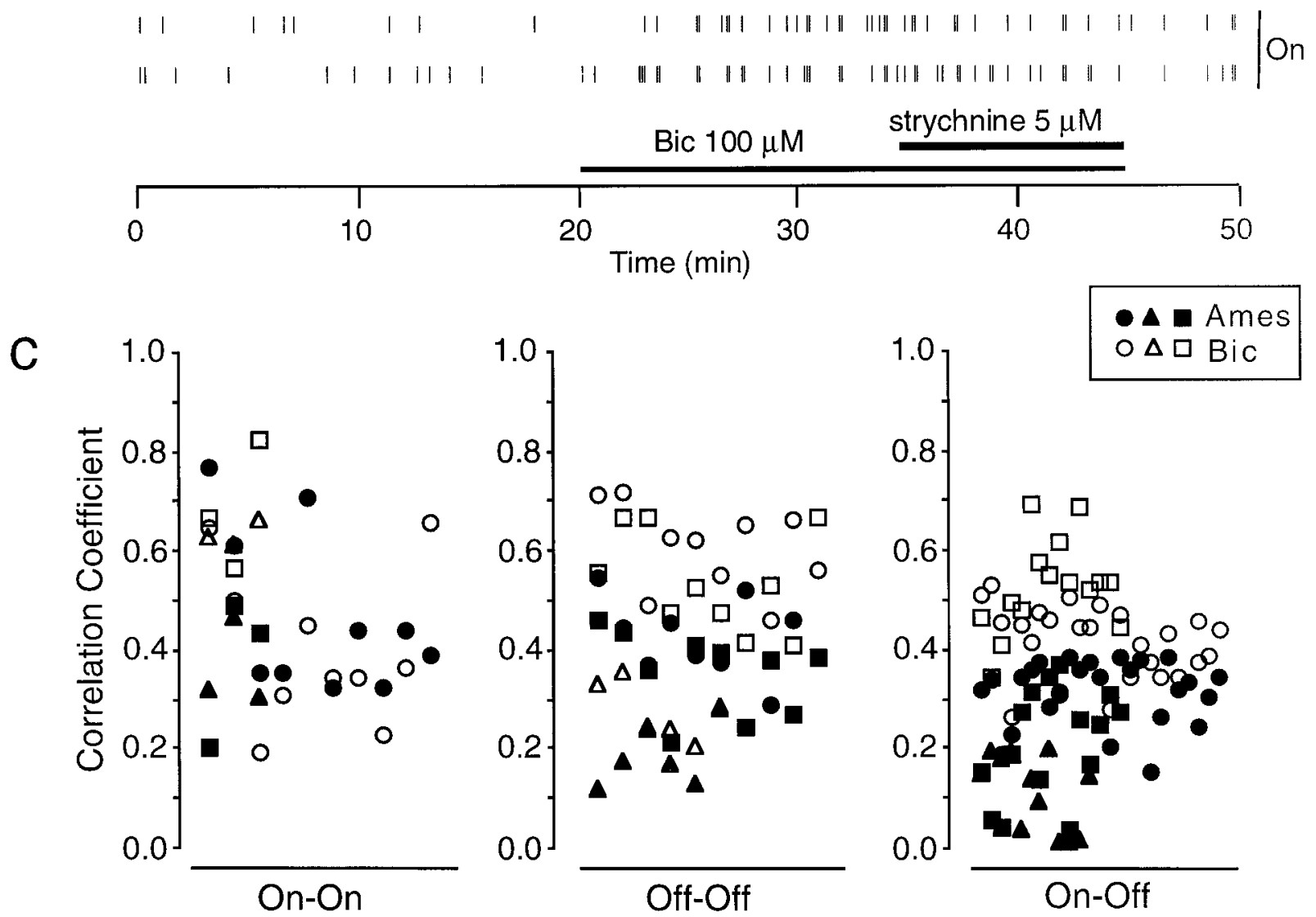

Figure 8. Raw plots of $\left[\mathrm{Ca}^{2+}\right]_{\mathrm{i}}$ are converted to raster plots (see Materials and Methods) to perform cross-correlation analysis on the bursts. $a$, An example of a recording from a P20 retina that depicts the raw data (top), the differential plot (bottom), and the corresponding raster plot (middle). The solid horizontal line in the differential plot depicts a threshold below which the baseline data points are "filtered out." Each solid dot in the raw data trace represents a value obtained within one image frame. $b$, Examples of raster plots for $\beta$-cells in the presence and absence of bicuculline (Bic) and strychnine. $c$, Correlation coefficients between On-On, Off-Off, and On-Off cells for three P22-P24 retinae in Ames medium (solid symbols) and in the presence of bicuculline (open symbols). A coefficient of 1.0 indicates perfect correlation between the bursts of the cells, and a coefficient of 0.0 indicates that the cells burst independently of each other. The observation that the coefficients are positive indicates that all cells (On and Off) burst synchronously when they exhibit a burst (see Wong and Oakley, 1996). Each symbol represents cells from the same recorded region of the retina. The change in the coefficients for each cell pair can be observed by comparing the values of the solid symbol (e.g., solid triangle) and the open symbol (open triangle) plotted immediately above or below. Note that the coefficient value for every On-Off pair increased in the presence of bicuculline. 
density of GABAergic inputs formed on On compared with Off ganglion cells by P18. Another possibility is that GABAergic inhibition is more strongly developed in On compared with Off cells, owing to differences in $\left[\mathrm{Cl}^{-}\right]_{\mathrm{i}}$ in these cells during the second and third postnatal week. Measurements of $E_{\mathrm{C} 1}$ for On and Off cells at these ages will provide more insight into the mechanism underlying the differential GABA effects.

In the absence of GABAergic transmission, the burst frequency of On cells, although increased, does not match that of Off cells. Thus, there are mechanisms, other than GABAergic inhibition, that contribute to the differences in On and Off bursting rates. One possibility is that $\mathrm{On}$ and Off bipolar cells also contribute to generating the differences in On and Off ganglion cell bursting activity; the period when On and Off cells develop distinct bursting rhythms (after the second postnatal week) coincides with the initial formation of bipolar ribbon synapses in the IPL (Greiner and Weidman, 1981). As On bipolar cells are hyperpolarized and Off bipolar cells are depolarized in the dark (for review, see Wässle and Boycott, 1991), spontaneous patterns of activity of On and Off ganglion cells may reflect the activity of their presynaptic bipolar cells. Although glutamate does not seem to play a prominent role in the waves early in development (Wong et al., 1995), the possibility that bipolar cells may contribute to the differences in On and Off ganglion cell rhythms as their connections mature has not been eliminated. In addition, GABAergic modulation of the bursting activity could also take place at the level of the bipolar cell axonal terminals that bear $\mathrm{GABA}_{\mathrm{A}}$ and $\mathrm{GABA}_{\mathrm{C}}$ receptors (Lukasiewicz and Wong, 1997).

How does GABAergic modulation of the retinal bursting activity affect the competition between On and Off inputs for postsynaptic targets in the geniculate nucleus? The current data indicate that GABAergic inhibition reduces the degree to which the bursts of On and Off cells are correlated during the period when On and Off sublaminae emerge in the dLGN. Such a reduction in the correlation strength between the activity of On and Off cells could lead to the segregation of their connections at the dLGN (see Lee and Wong, 1996; Miller, 1996). In addition, Off ganglion cells appear to burst more in synchrony in the absence of GABAergic transmission; GABAergic inhibition may therefore decrease the competitive advantage that Off cells might normally have based on their higher mean bursting rates by reducing their correlation strength (Miller, 1996). Thus, GABAergic modulation in the retina may help regulate the competitive interactions that take place in the dLGN by affecting not only the correlations in the activity between On and Off ganglion cells but also that between Off and Off ganglion cells.

\section{REFERENCES}

Bähring R, Standhardt H, Arrigoni Martelli E, Grantyn R (1994) GABA-activated chloride currents of postnatal mouse retinal ganglion cells are blocked by acetylcholine and acetylcarnitine: how specific are ion channels in immature neurons? Eur J Neurosci 6:1089-1099.

Ben-Ari Y, Tseeb V, Raggozzino D, Khazipov R, Gaiars JL (1994) Gamma-aminobutyric acid (GABA): a fast excitatory transmitter which may regulate the development of hippocampal neurones in early postnatal life. Prog Brain Res 102:261-273.

Burgi PY, Grzywacz NM (1994a) Model based on extracellular potassium for spontaneous synchronous activity in developing retinas. Neural Comput 6:983-1004.

Burgi PY, Grzywacz NM (1994b) Model for the pharmacological basis of spontaneous synchronous activity in developing retinas. J Neurosci 14:7426-7439.

Chen G, Trombley P, van den Pol AN (1996) Excitatory actions of
GABA in developing rat hypothalamic neurones. J Physiol (Lond) 494:451-464.

Constantine-Paton M, Cline HT, Debski E (1990) Patterned activity, synaptic convergence, and the NMDA receptor in developing visual pathways. Annu Rev Neurosci 13:129-154.

Cramer KS, Sur M (1997) Blockade of afferent impulse activity disrupts on/off sublamination in the ferret lateral geniculate nucleus. Dev Brain Res 98:287-290.

Feller MB, Wellis DP, Stellwagen D, Werblin FS, Shatz CJ (1996) Requirement for cholinergic synaptic transmission in the propagation of spontaneous retinal waves. Science 272:1182-1187.

Goodman CS, Shatz CJ (1993) Developmental mechanisms that generate precise patterns of neuronal connectivity. Cell 72:77-98.

Greiner JV, Weidman TA (1981) Histogenesis of the ferret retina. Exp Eye Res 33:315-332.

Hahm JO, Langdon RB, Sur M (1991) Disruption of retinogeniculate afferent segregation by antagonists to NMDA receptors. Nature 351:568-570.

Han YH, Zhang J, Slaughter MM (1997) Partition of transient and sustained inhibitory glycinergic input to retinal ganglion cells. J Neurosci 17:3392-3400.

Hebb DO (1949) The organization of behaviour. New York: Wiley.

Henderson Z, Finlay BL, Wickler KC (1988) Development of ganglion cell topography in ferret retina. J Neurosci 8:1194-1205.

Karne A, Wong GK, Oakley DM, Wong ROL (1997) Immunocyto-

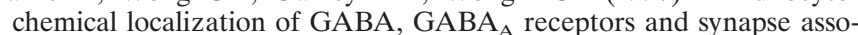
ciated proteins in the developing and adult ferret retina. Vis Neurosci 14:1097-1108.

Katz LC, Shatz CJ (1996) Synaptic activity and the construction of cortical circuits. Science 274:1133-1138.

Lee CW, Wong ROL (1996) Developmental patterns of On/Off retinal ganglion cell activity lead to segregation of their afferents under a Hebbian synaptic rule. Soc Neurosci Abstr 22:1202.

Leinekugel X, Medin I, Khalilov I, Ben-Ari Y, Khazipov R (1997) $\mathrm{Ca}^{2+}$ oscillations mediated by the synergistic excitatory actions of $\mathrm{GABA}_{\mathrm{A}}$ and NMDA receptors in the neonatal hippocampus. Neuron 18:243-255.

Lukasiewicz PD, Roeder RC (1995) Evidence for glycine modulation of excitatory synaptic inputs to retinal ganglion cells. J Neurosci 15:4592-4601.

Lukasiewicz PD, Wong ROL (1997) GABAc receptors on ferret retinal bipolar cells; a diversity of subtypes in mammals? Vis Neurosci 14:989-994.

Meister M, Wong ROL, Baylor DA, Shatz CJ (1991) Synchronous bursts of action potentials in ganglion cells of the developing mammalian retina. Science 252:939-943.

Miller KD (1996) Synaptic economics: competition and cooperation in synaptic plasticity. Neuron 17:371-374.

Miller KD, Keller JB, Stryker MP (1989) Ocular dominance column development: analysis and simulation. Science 245:605-615.

Mooney R, Penn AA, Gallego R, Shatz CJ (1996) Thalamic relay of spontaneous retinal activity prior to vision. Neuron 17:863-874.

Nelson R, Famiglietti EV, Kolb H (1978) Intracellular staining reveals different levels of stratification for on-centre and off-centre ganglion cells in the cat retina. J Neurophysiol 41:472-483.

Nguyen QT, Lichtman JW (1996) Mechanism of synapse disassembly at the developing neuromuscular junction. Curr Opin Neurobiol 6:104-112.

Penn AA, Wong ROL, Shatz CJ (1994) Neuronal coupling in the developing mammalian retina. J Neurosci 14:3805-3815.

Rohrbough J, Spitzer N (1996) Regulation of intracellular $\mathrm{Cl}^{-}$levels by $\mathrm{Na}^{+}$-dependent $\mathrm{Cl}^{-}$cotransport distinguishes depolarizing from hyperpolarizing $\mathrm{GABA}_{\mathrm{A}}$ receptor-mediated responses in spinal neurons. J Neurosci 16:82-91.

Sernagor E, Grzywacz NM (1994) Synaptic connections involved in spontaneous correlated bursts in the developing turtle retina. Invest Ophthalmol Vis Sci 35:2125.

Sernagor E, Grzywacz NM (1996) Influence of spontaneous activity and visual experience on developing retinal receptive fields. Curr Biol 6:1503-1508.

Stryker MP, Strickland SL (1984) Physiological segregation of ocular dominance columns depends on the pattern of afferent electrical activity. Invest Opthalmol Vis Sci [Suppl] 25:278.

Wässle H, Boycott BB (1991) Functional architecture of the mammalian retina. Physiol Rev 71:447-480. 
Weliky M, Katz LC (1997) Disruption of orientation tuning in visual cortex by artificially correlated neuronal activity. Nature 386:680-685.

Willshaw DJ, von der Malsburg C (1976) How patterned neural connections can be set up by self-organization. Proc R Soc Lond [Biol] 194:431-445.

Wingate RJ, Thompson ID (1995) Axonal target choice and dendritic development of ferret beta retinal ganglion cells. Eur J Neurosci 7:723-731.

Wingate RJ, Fitzgibbon T, Thompson ID (1992) Lucifer yellow, retrograde tracers, and fractal analysis characterise adult ferret retinal ganglion cells. J Comp Neurol 323:449-474.
Wong ROL, Oakley DM (1996) Changing patterns of spontaneous bursting activity of On and Off retinal ganglion cells during development. Neuron 16:1087-1095.

Wong ROL, Meister M, Shatz CJ (1993) Transient period of correlated bursting activity during development of the mammalian retina. Neuron 11:923-938.

Wong ROL, Chernjavsky A, Smith SJ, Shatz CJ (1995) Early functional neural networks in the developing retina. Nature 374:716-718.

Yuste R, Katz LC (1991) Control of postsynaptic $\mathrm{Ca}^{2+}$ influx in developing neocortex by excitatory and inhibitory neurotransmitters. Neuron 6:333-344. 